www.jmscr.igmpublication.org

Impact Factor (SJIF): 6.379

Index Copernicus Value: 79.54

ISSN (e)-2347-176x ISSN (p) 2455-0450

crossrefDOI: https://dx.doi.org/10.18535/jmscr/v6i10.178

\title{
Collision Tumor of Thyroid: A Rare Case Report
}

\author{
Authors \\ Khethmal $\mathbf{P}^{\mathbf{1}}$, Arun Kumar ${ }^{2}$ \\ ${ }^{1}$ Senior Resident, Department of Pathology, Government Medical College Thrissur, Kerala, India \\ ${ }^{2}$ Junior Resident, Department of Pathology, Government Medical College Thrissur, Kerala, India \\ Mobile no: 9447713650 Email:akrs-89@yahoo.com \\ Corresponding Author \\ Khethmal P \\ Mobile no:7034193004, Email: dr.kethmalrajpurohit@gmail.com
}

\section{Introduction}

Co existence of two or more independent, histologically distinct tumors separated by non neoplastic stroma in the same organ is collision tumor. It is different from composite tumors, which are composed of different tumor in close proximity with histologic intermingling of tumor cells. collision tumors within thyroid are rare.

\section{Case History}

A 84 yr old female with swelling in front of neck since $10 y$ rs duration presented to casualty with stridor. Examination revealed multinodular goiter. TFT was within normal limits. Emergency airway management followed by total thyroidectomy was done. Gross examination shows nodularly enlarged thyroid cut section identified three gray white growth larger one measures $6.5 \mathrm{~cm} \times 2 \mathrm{~cm}$ with central scar, Smaller measures $4 \times 3 \mathrm{~cm}$, Smallest measures $0.8 \mathrm{~cm}$ in GD. The final pathology report revealed Hurthle cell carcinoma with capsular and vascular invasion (fig 1) Follicular carcinoma with capsular and vascular invasion
(Fig 2) and Papillary carcinoma (Fig 3). There is no evidence of extrathroid extension.

Grossly cut section shows three gray white growth

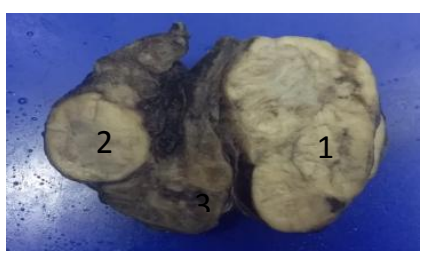

1. Encapsulated gray white growth with central scar and capsular invasion

2. Encapsulated gray white growth with capsular invasion

3. Gray white growth
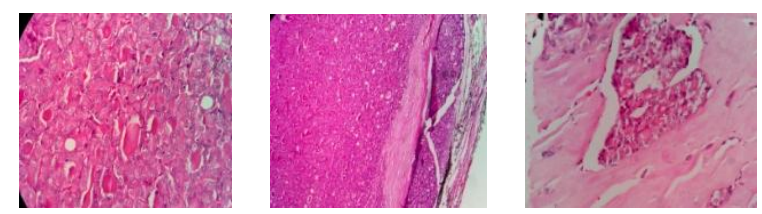

Fig 01 Hurthle cell carcinoma with capsular and vascular invasion 


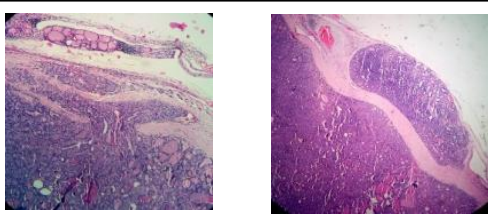

Fig 02A Follicular carcinoma with capsular invasion

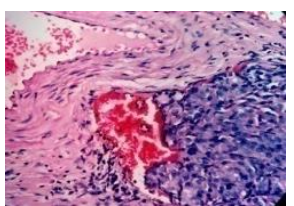

Fig 02B Follicular carcinoma with vascular invasion

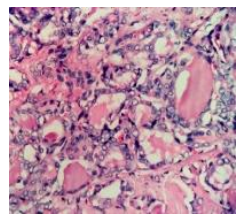

Fig 03 Papillary carcinoma

\section{Discussion}

Collision tumor has been reported in oral cavity, stomach, liver, kidney, cervix and ovary. Here we had a combination of Hurthle cell carcinoma, Follicular carcinoma, Papillary carcinoma in thyroid. Theories proposed for such occurrence are stem cell theory, Collision theory and Hostage theory. It is important to clinically recognize these tumors because of biopsy of only the benign component can have adverse consequence. These tumors should be considered more aggressive and higher risk of recurrence. Treatment should be patient specific and is directed by the more aggressive of the tumors. This emphasizes the importance of detailed histopathological examination and recognition of second neoplasm as prognosis and survival may be determined by this component.

\section{Conclusion}

Collision tumors of thyroid gland are rare. They are diagnostic as well as therapeutic challenge due to dual pathology. Specific treatment guidelines are not available due to paucity of reported literature on these tumors. Greater understanding of various combination of pathology and their impact on prognosis, treatment, and potential for recurrence will make standardized diagnostic and treatment protocol to be evolved.

\section{References}

1. Brandwein-Gensler M, Urken $M$, Wang B (2004) Collision tumor of the thyroid: a case report of metastatic liposarcoma plus papillary carcinoma. Head Neck 26:637641

2. Baloch ZW, Mandel S, LiVolsi VA. Combined tall cell carcinoma and hurthle cell carcinoma of the thyroid . Arch Pathol Lab Med 2001;125:541-3

3. Rossi S, Fugazzola L, De Pasquale L (2005) Medullary and Papillary carcinoma of the thyroid gland occurring as a collision tumor. Endocr Relat Cancer 12: 281-289

4. Ryan N,Walkden G, Lazic D, Tierney P. Collision tumor of the hyroid: Acase report nad review of literature. Head Neck 2015;37:E125-9 